\title{
A DISCUSSION ON THE ISSUE OF COSTS IN RELATION TO DERIVATIVE PROCEEDINGS IN SECTION 165 OF THE COMPANIES ACT 71 OF 2008*
}

\author{
Darren Subramanien \\ LLB LLM PhD \\ Senior Lecturer, School of Law \\ University of KwaZulu-Natal
}

\section{SUMMARY}

A historical practical obstacle to the institution of derivative proceedings has been the burden of costs. The burden of costs was identified as problematic as long ago as 1970 in the Van Wyk De Vries Commission of Inquiry into Companies and has the potential to continue to disincentivise derivative proceedings in light of the provisions of section 165 of the Companies Act 71 of 2008. Comparable provisions in the United Kingdom Companies Act 2006 are discussed to identify whether any improvements can be made with respect to the issue of costs in instituting derivative proceedings under section 165.

\section{$1 \quad$ INTRODUCTION}

The issue of costs and liability for costs involved in the derivative action was always a major concern. In 1970, the Van Wyk De Vries Commission of Inquiry into the Companies Act found that probably the biggest impediment to a derivative action was the risk that the plaintiff shareholder would have to bear the costs of the litigation. ${ }^{1}$ The issue of costs continues to be a disincentive for prospective applicants in instituting derivative proceedings under the Companies Act 71 of 2008. Section 165 does not alleviate the burden on applicants regarding costs of the derivative proceedings and therefore applicants rarely institute derivative proceedings owing to the risk of being held personally liable for a costs order or several costs orders. This article discusses the issue of costs and its implication on the institution of derivative proceedings.

* This article is based on sections of the author's PhD thesis.

Van Wyk de Vries Commission of Enquiry into the Companies Act: Main Report (RP 45 of 1970) (1970) par 42.12; see also "Company Law for the 21st Century: Guidelines for Corporate Law Reform" GN 1183 in GG 26493 of 2004-06-23 par 2.2.2. 
A comparative approach has been adopted in this article. The United Kingdom (UK) has been chosen as a comparator because, historically, the framework of South African company law has its foundations in law that existed in Victorian England in the middle of the nineteenth century. ${ }^{2}$ Both the Companies Act 46 of 1926 and the Companies Act 61 of 1973 (1973 Act) were still largely based on the framework and general principles of the English law. ${ }^{3}$ The main objective of the article is to compare the relevant provisions in the UK Companies Act of 2006 with the comparable provisions in the Companies Act 71 of 2008 (2008 Act), which may thus be useful in providing solutions, guidelines and warnings that can be used to supplement lacunae or defects in the South African legislation.

Section 5(2) of the 2008 Act provides that, to the extent appropriate, a court interpreting or applying the Act may consider foreign company law. Section 5(2) states further that the Act must be interpreted and applied in a manner that gives effect to section 7 , which sets out the purposes of the Act. ${ }^{4}$

The provisions in the 2008 Act also importantly adopt principles and values that are enshrined in the Constitution of South Africa. ${ }^{5}$ It would not be possible to undertake any analysis of the provisions of the 2008 Act without referring to the Constitution, which is the supreme law of the land. The Bill of Rights, as provided for in Chapter 2 of the Constitution, constitutes a cornerstone of democracy in South Africa. It not only enshrines the rights of all people in the country and affirms the democratic values of human dignity, equality and freedom but also regulates the relationship between economic citizens and thus may have fundamental implications for company law. ${ }^{6}$

It is with these principles in mind that a comparison of the relevant sections of the 2008 Act and the UK Companies Act 2006 have been undertaken.

2 Tong Review of Company Law in South Africa: Should South Africa Follow the British Example in Corporate Governance Matters This Time? (unpublished LLM dissertation, University of Natal Durban) 2003.

3 Ibid. See General Notice 1183 in GG 26493 of 2004-06-23 www.info.gov.za/ notices/2004/26493/ (accessed 2020-11-27); Cassim and Cassim "The Reform of Corporate Law in South Africa" 2005 16(10) The International Company and Commercial Law Review 411-418.

4 See Count Gotthard SA Pilati v Witfontein Game Farm (Pty) Ltd [2013] 2 All SA 190 (GNP) 15.4; Zoneska Investments (Pty) Ltd t/a Bonatla Properties (Pty) Ltd v Midnight Storm Investments 386 Ltd $(9831 / 2011,7811 / 2012)$ [2012] ZAWCHC 163; [2012] 4 All SA 590 (WCC) (28 August 2012).

5 Constitution of the Republic of South Africa, 1996.

6 See S v Makwanyane 1995 (3) SA 391 (CC) 35-36; Amdocs SA Joint Enterprise (Pty) Ltd v Kwezi Technologies (Pty) Ltd 2014 (5) SA 532 (GJ). 


\section{THE ISSUE OF COSTS IN SECTION 266 OF THE COMPANIES ACT 611973}

Arguably the greatest disincentive for minority shareholders in bringing statutory derivative actions in South Africa has been the cost of the action. ${ }^{7}$ Under section 266 of the 1973 Act, there were risks involved for the shareholder who initiated the statutory derivative action although the shareholder did not become personally involved in the litigation as a result of the appointment of a provisional curator ad litem, and because the action was eventually brought in the name of the company. ${ }^{8}$ The Van Wyk de Vries Commission stated that the issue of costs, including the fees charged by the provisional and ultimate curator ad litem, should be left to the discretion of the court. ${ }^{9}$ In addition, it was the view of the Commission that the issue of costs would "without any doubt" discourage frivolous or vexatious actions by minority shareholders. ${ }^{10}$

Section 268 of the 1973 Act provided as follows:

"The Court may, if it appears that there is reason to believe that the applicant in respect of an application under section 266(2) will be unable to pay the costs of the respondent company if successful in its opposition, require sufficient security to be given for those costs and costs of the provisional curator ad litem before a provisional order is made."

Only when the court appointed the curator ad litem and when the curator ad litem initiated the proceedings on behalf of the company was the action referred to as a statutory derivative action. ${ }^{11}$ Prior to this, the risk of a costs order was borne by the shareholder who initiated the proceedings. The court could ensure that the initiating shareholder appreciated the potential consequences of making frivolous or vexatious claims by exercising its discretion under section 268 of the 1973 Act. ${ }^{12}$ The shareholder who initiated the proceedings could be required to provide sufficient security for the costs of the application and costs of the provisional curator ad litem before a provisional order was made. The court would require such security if there was reason to believe that the applicant in respect of an application under section 266(2) was unable to pay the costs of the respondent company. ${ }^{13}$ Consequently, there was potentially a considerable financial risk and burden placed on the initiating shareholder owing to security needing to be provided.

7 Du Plessis "The South African Statutory Derivative Action: Background, Comparisons and Application" in Hugo and Kelly-Louw (eds) Essays on the Law of Banking, Companies and Suretyship (2017) 266.

8 Ibid.

9 Du Plessis in Hugo and Kelly-Louw Essays on the Law of Banking, Companies and Suretyship 266; see also Van Wyk de Vries Commission of Enquiry into the Companies Act par 42.16.

10 Van Wyk de Vries Commission of Enquiry into the Companies Act par 42.17.

11 Du Plessis in Hugo and Kelly-Louw Essays on the Law of Banking, Companies and Suretyship 267.

12 Ibid.

13 Hurter Aspekte Van Statutere Minderheidsbeskerming in die Suid-Afrikaanse Maatskappyereg (unpublished LLD thesis, University of South Africa) 1996320. 
This was probably the most significant reason that section 266 of the 1973 Act was used very infrequently. ${ }^{14}$

In summary, if the court refused to allow the action to continue, the unsuccessful party, in the absence of circumstances that justified a different order, would have been liable to pay the costs, including the costs of the initial application and all costs incurred by the provisional curator ad litem. If, however, the court confirmed the appointment of the curator ad litem, it meant that the company was liable for the costs of the proceedings if unsuccessful, which included all the costs incurred by the provisional curator ad litem and the ultimate curator ad litem. ${ }^{15}$

\section{THE ISSUE OF COSTS IN SECTION 165 OF THE COMPANIES ACT 71 OF 2008}

Section 165 of the Companies Act 71 of 2008 (2008 Act) provides that if a court grants leave to a person to sue on behalf of the company, the court is empowered to make an order regarding who would be liable for the remuneration and expenses of the person appointed as the investigator (this is the person who has been appointed to investigate the demand that has been served upon the company to commence or continue legal proceedings or to take related steps to protect the legal interests of the company). There is no similar provision on determining the liability for costs in section 165 where a committee or investigator instead of the person who is appointed to investigate. There is a lack of clarity in the 2008 Act as to whom the person appointed refers to. The "person appointed" may refer to the person appointed by the company to investigate the demand, or it could be interpreted to refer to the person who has been granted leave by the court to institute the derivative action. The section provides that a party or any of the parties may be liable to the proceedings or application, and the company may be liable. If the order makes two or more persons liable, it may also determine the nature and extent of the liability of each of those persons. The court may also vary the order as it sees fit. ${ }^{16} \mathrm{It}$ is submitted that the section does not provide clarity on who exactly will be liable for expenses in the proceedings. The Act may be referring to the person appointed by the company to investigate the demand, or it could refer to the person who is granted leave by the court to conduct the action under section $165 .{ }^{17} \mathrm{It}$ is submitted that further clarity should have been given by the legislature in this regard.

In Lewis Group Limited $v$ Woollam, ${ }^{18}$ the court confirmed that proceedings brought or intervened in with leave of the court must not be discontinued,

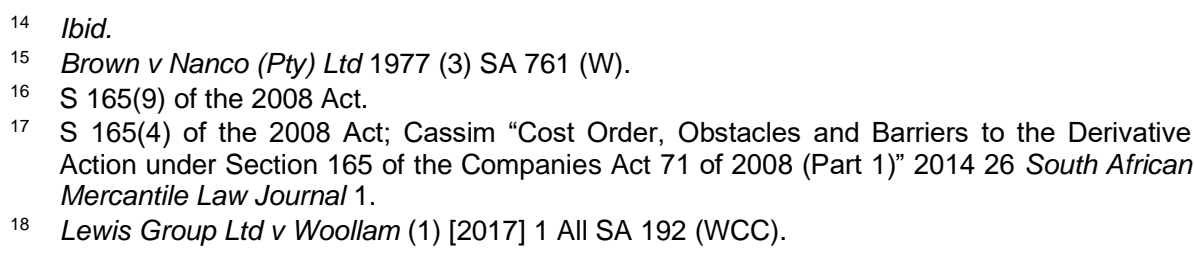

S 165(4) of the 2008 Act; Cassim "Cost Order, Obstacles and Barriers to the Derivative Action under Section 165 of the Companies Act 71 of 2008 (Part 1)" 201426 South African Mercantile Law Journal 1.

18 Lewis Group Ltd v Woollam (1) [2017] 1 All SA 192 (WCC). 
compromised or settled without leave of the court. ${ }^{19}$ This is a positive aspect of section 165 as it allows the court control over any settlements made in the derivative proceedings. The court is empowered to consider the interests of the company thereby ensuring fairness in the settlements reached. This also prevents parties from engaging or agreeing settlements unlawfully in their own interests and is a safeguard against directors and shareholders who wish to exercise undue influence on a person who wishes to discontinue the proceedings or reach an unacceptable compromise or settlement. The subsection also enables the court to determine whether the application was frivolous or vexatious and enables the applicant to decide whether to abandon the action because of the possibility of a large costs order. ${ }^{20}$ Section 165 provides further that the court at any time may make any orders it considers appropriate about the costs of certain persons in relation to the proceedings - namely, the person who applied for, or was granted leave; the company; or any other party to the proceedings or application. ${ }^{21}$

Although this provision gives a court a wide discretion, it fails to move the burden and risk of the costs issue from the applicant to the company, especially in instances where the applicant may lose the action. The possibility of being burdened with a costs order continues to be of serious concern to an applicant under section 165 and the section does not completely eradicate the risk to the applicant in derivative proceedings. ${ }^{22}$ According to Cassim, the new derivative proceedings under section 165 do not do enough to alleviate the burden of costs on the applicants. ${ }^{23}$

The applicant shareholder under section 165 institutes action, not in a personal capacity (as under section 163) but in the interests of the company. Therefore, the recovery of any financial gain or benefit is made to the company and not directly to the applicant, notwithstanding that all the shareholders may benefit from an increase in value of the company's shares. ${ }^{24}$ However, this creates the possibility that a few shareholders may seek to benefit from a successful action without themselves carrying the risk of costs. Cassim refers to this situation as the "free rider" effect where only a few shareholders would risk their time, effort and finances in instituting a derivative action while those shareholders who decide not to take any action (the so-called free riders) will benefit from the outcome of the derivative action. ${ }^{25}$

The increase in value of shares, however, does not deal with the legal costs and expenses that have been incurred by the applicant shareholder. In cases where the applicant has succeeded in the action, the applicant shareholder may still only be able to recover a portion of the expenses in terms of the "loser pays" principle that exists in South African civil procedure.

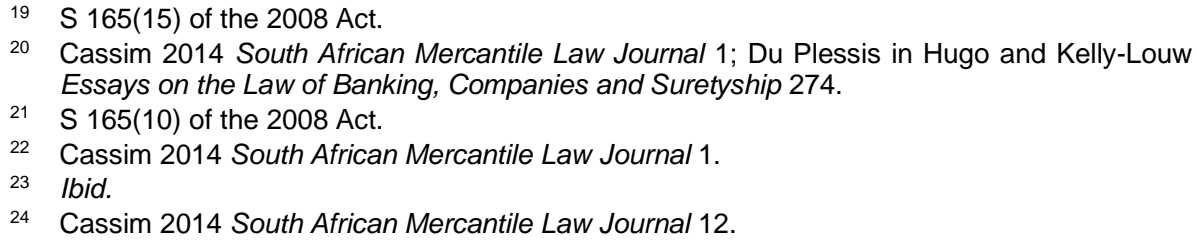


The applicant institutes the derivative claim on behalf of the company. Therefore, it is the company that is entitled to the award and not the applicant. In instances where the court awards costs on a party-and-party scale, the successful applicant would only be entitled to recover the costs incurred in the course of instituting the derivative claim and would not be reimbursed for costs that have been incurred over and above party costs. ${ }^{26}$ It is submitted that if applicants have to bear the costs of a derivative claim while at the same time not being able to benefit directly from a successful action, applicants may not be willing to institute derivative claims. Shareholders may choose to sell their shares and exit the company rather than run the risk of expensive litigation. ${ }^{27}$ Section 266 of the 1973 Act gave the courts a discretion to order the applicants to provide security for the application and curator ad litem. This provision served as an obstacle to the derivative action claims because of the significant financial burden it placed on applicants when required to provide security for costs. The applicant would be required to provide security for costs if the court was of the view that the applicant would not be able to satisfy the costs of the respondent company. The eventual amount could potentially include the costs in bringing the derivative action, the costs of appointing a provisional curator ad litem, the costs of the report prepared by the curator ad litem and the costs of the investigation to be conducted by the curator ad litem. ${ }^{28}$

Section 165(11) also grants the court a discretion to determine whether the applicant shareholder should provide security for costs. This provision creates further obstacles to the applicant shareholder as the amount required to cover the security may prove to be out of reach of the shareholder. This provision has the potential to disincentivise an application especially where litigation proceedings could continue for a sustained period for which the applicant shareholder would not be able to commit financial resources. ${ }^{29}$ The security-for-costs provision is largely seen to be designed to protect the financial resources of the company, and to curb collusive settlements as well as frivolous and vexatious actions. It is submitted that there is a greater risk that applicants will be deterred from instituting a legitimate derivative claim because of a lack of financial support or indemnity for costs than that a frivolous or vexatious claim will be made. It is submitted that the current situation regarding indemnity for costs undermines good corporate governance as the protection of the interests of the company against wrongdoing is in doubt. Cassim opines that there is no true rationale for a security-for-costs provision as section 165(15) is already in the Act to prevent collusive settlements. ${ }^{30}$

26 Ibid. See Whincop "The Role of the Shareholder in Corporate Governance: A Theoretical Approach" 200125 Melbourne University Law Review 418 422-424. Party-and-party costs in this context refers to only those costs that were necessarily incurred in the course of instituting or defending the derivative claim.

27 Cassim 2014 South African Mercantile Law Journal 13.

28 Hargovan "Under Judicial and Legislative Attack: The Rule in Foss V Harbottle" 1996113 South African Law Journal 631 650; see also Schreiner "The Shareholder's Derivative Action: A Comparative Study of Procedure" 197996 South African Law Journal 242-245.

29 Cassim 2014 South African Mercantile Law Journal 1.

30 lbid. 
The other possible reason for the provision dealing with security for costs is to protect the interests of the company as well as the directors should the action fail. But, according to Cassim, shareholders should not be put in a position where their personal wealth is used as a ground to disqualify them from instituting action; furthermore, there are other provisions in the Act designed to protect the company and directors such as those provisions found in section 78 of the Act. ${ }^{31}$ Section 78 provides that a company is permitted to indemnify a director against expenses in a derivative action or provide a director with finances in order to defend proceedings in a derivative action. If judgment is given against a director in cases where the director has committed willful misconduct or an intentional breach of trust, ${ }^{32}$ then the costs incurred will be repaid to the company. ${ }^{33}$ However, in cases where a director is found to be negligent, then the legal costs and liability is ratifiable by the company. ${ }^{34}$ The practical consequences of these provisions leave much to be desired. In instances where directors have acted negligently towards the company, they in effect bear no direct ill effects. They will not be held liable for payment or any reimbursement to the company of the costs involved in the defence of these actions. These provisions therefore have the effect of indemnifying the directors for their negligent actions. It is therefore submitted that a distinction must be drawn between directors' liability for negligence to third parties and liability for negligence to the company itself. This is a view supported by Cassim. ${ }^{35}$ Section 78 of the Act permits a company to acquire insurance to protect directors and indemnify them against liability or expenses. It is important to ensure here again that these provisions and the insurance provided therein, which in most instances may be paid by the company on behalf of the director, should not be used as a mechanism for a director to subvert his or her liability for negligence and the costs involved in defence of a claim. This surely must not have been the intention of the legislature. Further clarity is needed as to when these provisions may be used to prevent rendering them superfluous. ${ }^{36}$

Section 165 is silent as to whether the court has a discretion to permit recovery to current and former shareholders. It is submitted that currently there is the possibility that shareholders who were present at the time of the wrongful acts but have subsequently left the company will not be able to recover any expenses incurred when they were shareholders in the company. The failure of the Act to clarify this position leaves open the possibility of new shareholders being unjustifiably enriched, while former shareholders are denied the right to recover any financial portion they have expended while still shareholders. ${ }^{37}$

31 Ibid.

32 In terms of s 424 of the 1973 Act or in terms of $s 77(3)(a)-(c)$ of the 2008 Act, or, consists of a fine in terms of $s 78(3)$ of the 2008 Act.

33 S 78(4)-(6) read with s 78(8) of the 2008 Act.

34 S 78(4)-(6) of the 2008 Act.

35 Cassim "Cost Order, Obstacles and Barriers to the Derivative Action Under Section 165 of the Companies Act 71 of 2008 (Part 2)" 201426 South African Mercantile Law Journal 239.

36 Cassim 2014 South African Mercantile Law Journal 241.

37 Cassim 2014 South African Mercantile Law Journal 22. 
Cassim opines that direct payment of a pro rata portion of the proceeds in a successful action to current shareholders may be necessary in order to prevent abuse in cases where the true defendants were majority shareholders or controllers of the company. ${ }^{38}$ This would in effect, it is submitted, deter current shareholders from continuing or repeating the wrongdoing or from using the proceeds of the derivative action for their own purposes, thereby denying individual shareholders of the company any (direct or indirect) benefit of the recovery. ${ }^{39}$

A further anomaly in the 2008 Act regarding the liability for costs and expenditure in derivative proceedings pertains to section 165(9)(a) of the Act. In terms of the section, if the court grants leave to an applicant under section 165, the court must also make an order stating who is liable for the remuneration and expenses of "the person appointed". The section lacks clarity as it fails to indicate who is being referred to as the "person". The section leaves open whether the "person" is the person appointed by the court under section 165(4)(a) or whether it is referring to the person who made the demand under section 165(2). It is submitted that, if the section refers to the latter, then it should be the company that meets the applicant's expenses. If the court were to grant an order that the applicant would be liable for the expenses under section 165(9)(a), it would only increase the already heavy burden placed on applicants. Further clarity is needed in this respect.

\section{THE UNITED KINGDOM COMPANIES ACT 2006}

The courts were empowered under the common-law derivative action to indemnify a shareholder when an application is made to pursue a derivative action. Rule 19.9 E of the Civil Procedure Rules now regulates the power of the court to award costs. In terms of the rule, a court may order the company to indemnify the applicant shareholder against any costs incurred in relation to the permission or the derivative action or both. ${ }^{40}$

The financial implications of the derivative action are probably the most influential factor for an applicant shareholder when deciding whether or not to initiate a derivative action. In the UK, the issue of costs is of greater concern because the losing litigant may be held liable for the costs of the opposing party, and this is also the case regarding derivative actions. ${ }^{41}$

There have been differing views in the case law under common law and statute regarding the issue of costs. The courts have expressed the view that at common law an applicant shareholder who is able to persuade a

38 Cassim 2014 South African Mercantile Law Journal 22; Regal (Hastings) Ltd v Gulliver [1967] 2 AC 134; Cassim 2014 South African Mercantile Law Journal 231.

39 Boyle Minority Shareholders' Remedies (2002) 85; Cassim 2014 South African Mercantile Law Journal 22.

40 Keay "Assessing and Rethinking the Statutory Scheme for Derivative Actions Under the Companies Act 2006" 201616 Journal of Corporate Law Studies 24.

41 Reed "Derivative Claims: The Application for Permission to Continue" 200021 Company Law 156-158; Tang "Shareholder Remedies: Demise of the Derivative Claim?" 20151 UCL Journal of Law and Jurisprudence 183. 
court at the ex parte preliminary stage that the proceedings were justified should be indemnified for costs. ${ }^{42}$

In Wallersteiner v Moir (No. 2), ${ }^{43}$ Lord Denning MR stated:

"The minority shareholder, being an agent acting on behalf of the company, is entitled to be indemnified by the company against all costs and expenses reasonably incurred by him in the course of the agency ... Seeing that, if the action succeeds the whole benefit will go to the company, it is only just that the minority shareholder should be indemnified against the costs he incurs on its behalf." 44

The court indicated that the applicant shareholder should be indemnified for costs even if the claim is unsuccessful provided the applicant acted in good faith and on reasonable grounds. ${ }^{45}$ The rationale behind the court's order is that a company should indemnify a plaintiff in a derivative claim because the plaintiff is acting on behalf of the company and the company will directly benefit from a successful suit. ${ }^{46}$

In Smith $v$ Croft, ${ }^{47}$ the court held that the applicant shareholder, when applying for costs orders, must demonstrate that the award for costs is genuinely needed, and indicated that it may be appropriate to leave a proportion of the costs to the claimants as an incentive for the applicant to proceed with the derivative claim.

Lewison $\mathrm{J}$ in Lesini $v$ Westrip Holding $L t^{48}{ }^{48}$ rejected the view of the court in Smith $v$ Croft. The court held that indemnity costs orders are not limited to impecunious claimants. ${ }^{49}$ It is submitted that this was the correct approach by the court. An indemnity for a costs order that is awarded to the applicant should not be determined by the financial status of the applicant. The financial position of the applicant is irrelevant. The applicant initiates the action on behalf of the company for the wrongful actions perpetrated against it. The reward is then paid to the company. The applicant should then be reimbursed for the expenses involved in a successful action or for expenses in a successful claim where the losing party has to pay the costs of the litigation.

In Carlisle \& Cumbria United Independent Supporters' Society Ltd $v$ CUFC Holdings $L t d,{ }^{50}$ Arden LJ stated:

"As the action was a derivative action on behalf of the club, the trust [the applicant] had an expectation of receiving its proper costs from the companies

42 Keay 2016 Journal of Corporate Law Studies 24; Wallersteiner v Moir (No. 2) [1975] QB 371 391.

43 Supra.

44 Wallersteiner v Moir (No. 2) supra 391; see also Wilton UK Ltd v Shuttleworth [2018] EWHC $911(\mathrm{Ch}) 91$

45 Wallersteiner v Moir (No. 2) supra 403-404; Boyle Minority Shareholders' Remedies 36-37; Li A Comparative Study of Shareholders' Derivative Action (2007) 74.

46 Zhang The Derivative Action and Good Corporate Governance in China 204.

47 (1988) Ch. 114 580-581.

48 [2009] EWHC 2526 (Ch); [2010] BCC 420125.

49 See also Jaybird Group Limited $v$ Wood [1986] BCLC 319, 327.

50 [2010] EWCA Civ 463; [2011] BCC 855. 
on an indemnity basis if the action had gone forward."

This view was supported by the court in Stainer $v$ Lee, ${ }^{51}$ where the court held that a shareholder who obtains the permission of the court to proceed "should normally be indemnified as to his reasonable costs by the company. In Foyster $v$ Foyster Holdings Pty Ltd ${ }^{52}$ Barret $J$ stated that applicant shareholders should be indemnified against costs in legitimate cases as the applicant shareholders have initiated the derivative action to protect the interests of the company when others within the company have failed to do so. 53

The Commission indicated that the possibility of a costs indemnity order is a significant incentive to use the derivative action. ${ }^{54}$ But, according to Reisberg, the granting of costs or an indemnity against costs is not really an incentive. An incentive in the context of a derivative action assumes that the applicant shareholder will obtain some benefit or advantage that the applicant did not already have by initiating a derivative action. ${ }^{55}$ However, it is submitted that an award of an indemnity against costs does not provide the applicant with anything that the applicant did not already have, and neither has the applicant lost anything. But, in certain instances the applicant shareholder may suffer financially as the costs order may not reimburse the applicant for the finances expended in the hiring and briefing of attorneys in preparation for derivative litigation. ${ }^{56}$ The applicant would remain liable for these legal costs irrespective of the outcome of the case.

Owing to the lack of clear guidelines regarding indemnity for costs, applicant shareholders have no certainty regarding whether a court will come to their aid in providing an indemnity for costs. The court has a wide discretion regarding an indemnity for costs but this provides little comfort for an applicant who requires reimbursement for instituting action on the company's behalf. ${ }^{57}$ It is evident from the case law that the courts are inclined to make an award to indemnify an applicant against costs but these costs orders are limited. ${ }^{58}$ In Kiani $v$ Cooper, ${ }^{59}$ the court limited the indemnity for costs order in favour of the applicant but not in respect of an adverse costs order. Proudman $\mathrm{J}$ indicated that the applicant should assume part of

51 [2010] EWHC 1539 (Ch), [2011] 1 BCLC 53756.

52 Foyster v Foyster Holdings Pty Ltd [2003] NSWSC 13513.

53 See Keay 2016 Journal of Corporate Law Studies 25.

54 See Law Commission "Shareholder Remedies Consultation" (1996) http://lawcom.gov.uk/ _project/shareholder-remedies/ (accessed 2019-03-05) par 18.1.

55 Reisberg "Funding Derivative Actions: A Re-Examination of Costs and Fees as Incentives to Commence Litigation" 20044 Journal of Corporate Law Studies 355; Hargovan 1996 South African Law Journal 648; Keay 2016 Journal of Corporate Law Studies 26.

56 Keay 2016 Journal of Corporate Law Studies 26; Hannigan and Prentice Hannigan and Prentice: The Companies Act 2006 - A Commentary (2009) par 4.86.

57 Zhang The Derivative Action and Good Corporate Governance in China 204.

58 Keay 2016 Journal of Corporate Law Studies 26; Ramsay and Saunders "Litigation by Shareholders and Directors: An Empirical Study of the Statutory Derivative Action" 20066 Journal of Corporate Law Studies 432; see also Stainer v Lee supra where Roth J ordered an indemnity to a limit of $£ 40$ 000; Kiani v Cooper [2010] EWHC 577 (Ch); [2010] BCC 463 49.

59 Supra. 
the risk in keeping with the decision in Smith $v$ Croft, which indicated that only a portion of the costs should be indemnified to act as incentive to the applicant to continue to pursue the claim. In Stainer $v$ Lee, Roth J ordered an indemnity to a limit of $£ 40000$ but allowed for the possibility of an applicant applying for an extension of an indemnity for costs. The rationale of the court was that the applicant's costs could become excessively more and disproportionate to the amount eventually awarded to the company, which was uncertain at that point in the proceedings. ${ }^{60}$ Furthermore, the approach by the court in Stainer $v$ Lee allows the court to reassess the claim for indemnity for costs at every stage of the proceedings; at the same time, it ensures that there is a balance between a credible derivative claim and placing an undue burden on the personal financial status of the applicant.61 The approach in Stainer $v$ Lee provides relief to the applicant by postulating a type of interim funding that may be extended based on the ongoing degree of success of the applicant's case, which may be assessed at different stages of the proceedings. ${ }^{62}$

In Wishart Castlecroft Securities $L t d,{ }^{63}$ the court expressed a degree of wariness in writing a blank cheque to an applicant. The court therefore indicated that it would be appropriate to decide whether an award for costs should be granted during the permission-for-leave proceedings rather than the substantive hearing ${ }^{64}$ It is submitted that this view does have benefits for the applicant in that it provides a certain degree of clarity and certainty before the applicant decides to pursue the matter further - in which case the costs could increase substantially.

There is a lack of legislation and legal rules providing for indemnity for costs for shareholders. Keay submits that, as a result, there is a possibility that a company could be unjustly enriched, as it will be the recipient of the benefit from the shareholder's efforts in instances where a derivative claim is successful, and especially if the court does not make an order for the company to reimburse the shareholder. ${ }^{65}$ Furthermore, it is submitted that the lack of legislation and guidelines on an indemnity for the costs borne by shareholders serves as a disincentive to prospective applicants in instituting derivative claims. ${ }^{66}$ This results in the actions of wrongdoers going unpunished.

Although courts need to be wary of opening the floodgates to claims for costs by applicants in derivative proceedings, it must be kept in mind that

\footnotetext{
Stainer $v$ Lee supra 56.

Tang 2015 UCL Journal of Law and Jurisprudence 204.

Kaplan and Elwood "The Derivative Action: A Shareholder's Bleak House?" 200336 University of British Columbia Law Review 478.

63 (2009) CSIH 65, 2010 SC.

64 Wishart $v$ Castlecroft Securities Ltd supra 49 and 62; Tang 2015 UCL Journal of Law and Jurisprudence 204.

65 Keay 2016 Journal of Corporate Law Studies 28; Wilson "Attorney Fees and the Decision to Commence Litigation: Analysis, Comparison and an Application to the Shareholders' Derivative Action" 19855 Windsor Yearbook of Access to Justice 177 and referred to in Ramsay "Corporate Governance, Shareholder Litigation and Prospects for a Statutory Derivative Action" 199215 University of New South Wales Law Journal 149164.

66 Reisberg Derivative Actions and Corporate Governance (2007) 222.
} 
courts will only make an award for costs once the derivative action has been subject to judicial scrutiny. ${ }^{67}$ This takes into account the fact that UK legal rules provide for costs budgets to be provided by the litigants at what is known as a case-management hearing before the trial. This ensures greater control and analysis before any costs order is made. ${ }^{68}$

Tang submits that a balancing exercise must be adopted by the courts to ensure that the courts are not too generous or expansive in making awards indemnifying an applicant shareholder, and at the same are not too rigid and restrictive in rejecting claims for costs. ${ }^{69} \mathrm{It}$ is submitted in this article that this balancing exercise or dual consideration is not necessary, especially in instances where a successful applicant has acted in good faith to protect the interests of the company. It is submitted that an applicant in these cases should be indemnified for costs incurred and should not be restricted or inhibited from doing so.

It is submitted that if the courts are serious about protecting the interests of companies and ensuring good corporate governance then they need to be readier to award an indemnity for costs to shareholders who have successfully obtained permission to continue a derivative action.

\section{Contingency fee agreements}

A contingency fee agreement between attorney and client may serve as a mechanism to provide prospective applicant shareholders with an incentive to institute derivative proceedings. ${ }^{70}$ In terms of the agreement, if a client wins the case, the attorney will be able to charge the normal fee and an additional fee that does not exceed the normal fee by 100 per cent. However, if the client loses the case, the client is not liable for the attorney's fee. ${ }^{71} \mathrm{~A}$ contingency fee agreement has been used as a strong incentive to encourage derivative actions in the United States of America (US). ${ }^{72}$ In the UK, contingency fee agreements were historically regarded as being contrary to public policy but were introduced into English law by section 58 of the Legal Services Act $1990^{73}$ and have been used in criminal and family law cases. The application of contingency fee agreements in derivative proceedings in the UK remains uncertain as there has not been any case law embracing the concept in derivative proceedings. In Wallersteiner $v$ Moir

67 Li A Comparative Study of Shareholders' Derivative Action 74; Davies, Worthington, Micheler and Gower and Davies: Principles of Modern Company Law 8ed (2008) 455.

68 See Part 3 of the Civil Procedure Rules 1998 (SI 1998/3132), and the Court of Appeal's judgment in the Griffiths $v$ Solutia (UK) Ltd [2001] EWCA Civ 736; Keay 2016 Journal of Corporate Law Studies 29.

69 Tang 2015 UCL Journal of Law and Jurisprudence 203.

70 Li A Comparative Study of Shareholders' Derivative Action 75.

71 As per article 4 of the Conditional Fee Agreements Order 2000; see generally Andrews "Conditional Fee Agreements: The Courts and Parliament in Unison" 199857 Cambridge Law Journal 429; Boyle Minority Shareholders' Remedies 83.

72 Hirt The Enforcement of Directors' Duties in Britain and Germany: A Comparative Study with Particular Reference to Large Companies (2004) 133; Li A Comparative Study of Shareholders' Derivative Action 75.

73 Substituted by s 27(1) of the Access to Justice Act 1999. 
(No. 2), ${ }^{74}$ Lord Denning agreed in principle with conditional fee agreements being used in derivative proceedings. However, the majority of the Appeal Court held that the court did not have either the power or good reason to sanction the agreement. Authors have questioned the application of contingency fee agreements in the context of derivative proceedings. According to Boyle, it would be nonsensical to permit contingency fee agreements in derivative actions as any benefit that is awarded by the court in a successful claim must be paid to the company and not the applicant shareholder..$^{75}$ The shareholder therefore receives no right to the benefit of any award made. It is submitted that a contingency fee agreement serves as an incentive not to the applicant shareholder but to the applicant's attorneys, who, like the company, are the true benefactors of the contingency fee agreement in a successful action. For a contingency fee agreement to serve as a true incentive to applicants, an amendment to existing legislation or to the 2006 Act is necessary to provide for some benefit to the applicant when entering into such agreements, perhaps providing applicants with a pro rata share of the successful action which may then be used to satisfy their legal costs.

The possibility of being burdened with a costs order continues to be of serious concern to an applicant under section 165 of the 2008 Act and it is submitted that section 165(10) does little to alleviate the burden on an applicant who runs the risk of being held liable for the costs of the action. There has been no mention in case law or in statutes to date of the application of contingency fee agreements ${ }^{76}$ in respect of derivative claims and neither has there been any consideration as to whether the applicant could be awarded a pro rata share in successful derivative proceedings.

\section{Permission required before settlement or discontinuation of an action}

Once it has granted permission for the derivative action to continue, a court in the UK may order, under rule $19.9 \mathrm{~F}$ of the Civil Procedure Rules, that the claim constituted by the derivative action cannot be discontinued, settled or compromised without its permission. The power to make such an order is in the sole discretion of the court. Under section 165(15) of the 2008 Act, derivative proceedings brought or intervened in with leave of the court "must not be discontinued, compromised or settled without leave of the court". ${ }^{77}$ It is submitted that the South African approach is the more suitable one, because not only does section 165 give the court control over any settlements made in the derivative proceedings, but the section makes it compulsory for the court to grant permission for any discontinuance of the

74 Supra.

75 Boyle Minority Shareholders' Remedies 83; Li A Comparative Study of Shareholders' Derivative Action 76.

76 There is no mention in either the Contingency Fees Act 66 of 1997 or the Companies Act 71 of 2008 regarding contingency fees in derivative claims.

77 See Cassim 2014 South African Mercantile Law Journal 21; see also Du Plessis in Hugo and Kelly-Louw Essays on the Law of Banking, Companies and Suretyship 274; Lewis Group Ltd $v$ Woollam supra. 
proceedings. The court is empowered to consider the interests of the company and thereby ensure fairness in the settlements or compromises reached.

\section{CONCLUSION AND RECOMMENDATIONS}

It is submitted that the issue of costs continues to be a disincentive for prospective applicants in the institution of derivative proceedings under the 2008 Act. Section 165 does not alleviate the burden on applicants regarding costs of the derivative proceedings and therefore applicants rarely institute derivative proceedings owing to the risk of being held personally liable for a costs order or several costs orders. Section 165(10) allows a court, at any time, to make any order it considers appropriate about costs in the proceedings. It is submitted that this is insufficient, as it does not provide the applicant with any relief or indemnity for costs, especially as courts in South Africa adopt the "loser pays" principle in civil proceedings, which also applies in derivative proceedings. The applicants in derivative proceedings institute the derivative action on behalf of the company. Any award made by the court in a successful action is paid to the company. The practical effect of this is that applicants run the risk of being held liable for their own litigation costs as well the costs of the defendant if they lose a derivative action, and this may be exacerbated in instances where the applicant chooses to take the decision of the court a quo on appeal. In this instance, the legal costs incurred may increase substantially. Even in instances where the court awards costs to the successful applicant, an award on the party-and-party scale may prove unreasonable in derivative proceedings owing to the nature of derivative actions. Any order by the court regarding costs in this instance will relate only to the costs and disbursements incurred by the applicant in instituting the derivative action and will not cover the additional costs over and above the party-and-party costs.

It has been argued that potential liability for costs is necessary to prevent opening the floodgates to frivolous and vexatious derivative claims. ${ }^{78}$ However, it is submitted that liability for costs has a far more serious effect of discouraging derivative applications altogether, some of which are worthy in attempting to protect the interests of the company. It is submitted that one way to incentivise derivative applications by applicant shareholders would be to allow applicants to receive a pro rata share of an award, together with the company, in a successful derivative action. If prospective applicants are aware of the possibility of receiving a financial award in a successful derivative claim, this may not only encourage worthy derivative applications but also prevent frivolous and vexatious ones. However, granting successful applicants a pro rata share may contradict the derivative principle - in that the action was instituted on behalf of the company and the company is the only person truly entitled to any award. Therefore, a degree of flexibility would be required of the courts if the applicant is to be granted a pro rata share in the award. There also exists the option of the court making the company liable for a pro rata share of the litigation costs of the proceedings.

78 Reisberg Derivative Actions and Corporate Governance 222. 
Again, this would require a degree of flexibility by the court. However, the problem would remain that the applicant shareholder may still be liable to the shareholder's own attorneys for legal costs as the company would only be liable for a pro rata share of the defendant's costs.

It is submitted that the court must use its discretion when making an award for costs to prevent a situation where free riders who choose not to institute derivative proceedings are able to benefit from a successful action instituted by only a few shareholders. It is submitted that these free riders should be excluded from any award or indemnity for costs order.

The court is empowered under section 165(11) to use its discretion to determine whether the applicant shareholder should provide security for costs. It is submitted that this provision provides further obstacles to applicants as the amount of the security may prove beyond the applicant's means, especially in instances having the potential for lengthy litigation and instances where the applicant takes decisions by the court a quo on appeal. It is submitted that to expect an applicant to commit large amounts of money to derivative litigation for any sustained period is unfair and impractical, irrespective of the personal financial status of the applicant. ${ }^{79}$ The derivative litigation is instituted on behalf of the company and the applicant should not be forced to commit personal financial resources, especially in a situation where the applicant will not receive any remuneration from a successful derivative claim. It is submitted that the section further disincentivises applicants' derivative claims; not only is there a lack of provision for indemnity for costs but there is also the potential of having to pay security for costs.

The 2006 Act in the UK also fails to provide clarity regarding indemnity for costs to applicants instituting a derivative claim. The risk of being held liable for the costs of the defendant in a losing derivative claim and the liability for the applicant's own legal costs continues to be a deterrent to derivative proceedings in the UK. However, the court in Wallersteiner $v$ Moir (No. 2) ${ }^{80}$ did indicate that there might be some relief for applicant shareholders. The court indicated that, at common law, an applicant shareholder who can persuade a court at the ex parte preliminary stage that the proceedings are justified should be indemnified for costs. ${ }^{81}$

It is submitted that although this decision was expressed in relation to the common law, it may serve as a useful guide in the interpretation of section 165(10) with regard to the indemnity for costs for applicants under the section. In essence, as long as an applicant is able to show at the demand stage that the proceedings were justified, a court would be able to indemnify

\footnotetext{
Cassim 2014 South African Mercantile Law Journal 1.

Supra.

81 Wallersteiner $v$ Moir supra 391: "The minority shareholder, being an agent acting on behalf of the company, is entitled to be indemnified by the company against all costs and expenses reasonably incurred by him in the course of the agency ... Seeing that, if the action succeeds the whole benefit will go to the company, it is only just that the minority shareholder should be indemnified against the costs he incurs on its behalf"; see also Wilton UK Ltd v Shuttleworth supra 91; Keay 2016 Journal of Corporate Law Studies 24; Cassim The New Derivative Action Under the Companies Act (2016) 17.
} 
the applicant against costs. However, the UK courts themselves have been reluctant to apply the judgment in Wallersteiner $v$ Moir (No. 2) in other cases and have opted for a more restrictive approach in relation to indemnity for costs. For example, in Smith $v$ Croft, ${ }^{82}$ the court took into account the personal financial position of the applicant shareholder. It concluded that the applicant shareholder, in applying for costs orders, must demonstrate that the award for costs is genuinely needed and that it may be appropriate to leave a proportion of the costs to the claimants as an incentive for the applicant to proceed with the derivative claim. ${ }^{83}$ In essence, according to the court, wealthy applicants should not be entitled to an indemnity for costs. It is submitted that this is the incorrect approach. Applicants in a derivative claim institute action on behalf of the company and thus their personal financial status should not be a part of the equation. To pretend otherwise is to undermine the rationale behind derivative proceedings. ${ }^{84}$ The conflicting approach to indemnity for costs has left applicants in a precarious position regarding costs and has also led to costly and lengthy mini-trials. ${ }^{85}$

The courts in the UK have not utilised contingency fee agreements to alleviate the financial burden on applicants. ${ }^{86}$ There is no UK or South African legislation that provides for contingency fee agreements in the context of a derivative action. It is further submitted that for contingency fee agreements to be an incentive to applicants in derivative proceedings would require an alteration of the principle underpinning contingency fee agreements. Currently, if the contingency fee agreement were to apply in derivative actions it would be the company who would benefit as any award made by the court would have to be awarded to the company. ${ }^{87}$ The applicant shareholder is not the plaintiff and thus receives no benefit from such an agreement. It is submitted that currently any contingency fee agreement in the context of derivative proceedings serves only to incentivise the applicant's attorneys who would benefit and not the actual applicant.

The courts in the UK have been inclined to assert a degree of flexibility in certain instances and have provided an indemnity for costs for a limited amount only. ${ }^{88}$ This approach may serve as a guide to South African courts to allow for a portion of the applicants' costs to be indemnified in derivative proceedings without the court simply writing a blank cheque to applicants. ${ }^{89}$ It is submitted that receiving an indemnity for a costs order for a limited amount may serve as an incentive to institute derivative proceedings to

\footnotetext{
Supra.

Smith v Croft supra 580-581.

Cassim The New Derivative Action Under the Companies Act 17.

Sykes "The Continuing Paradox: A Critique of Minority Shareholder and Derivative Claims Under the Companies Act 2006" 201029 Civil Justice Quarterly 226.

86 In Wallersteiner $v$ Moir (No. 2) supra. Lord Denning agreed in principle with conditional fee agreements being used in derivative proceedings however, the majority of the Appeal Court held that the court did not have neither the power nor good reason to sanction the agreement.

87 Boyle Minority Shareholders' Remedies 83; Li A Comparative Study of Shareholders Derivative Action 76.

88 Kiani v Cooper supra; Stainer v Lee supra.

89 Wishart $v$ Castlecroft Securities Ltd supra.
} 
protect the interests of the company, especially in the absence of any amendment to existing legislation in regard to an indemnity for costs.

In terms of section 266 of the 1973 Act, although the initiating shareholder did not become personally involved in the litigation as a result of the appointment of a provisional curator ad litem, and because the derivative proceedings were eventually brought in the name of the company, there still remained a risk of costs for the initiating shareholder that ultimately resulted in the infrequent use of the statutory derivative action. ${ }^{90}$ The Van Wyk de Vries Commission expressly recommended that costs (including those costs relating to the fees charged by the provisional and ultimate curator ad litem) should be left to the discretion of the court. ${ }^{91}$ Section 268 of the 1973 Act provided as follows:

"The Court may, if it appears that there is reason to believe that the applicant in respect of an application under section 266(2) will be unable to pay the costs of the respondent company if successful in its opposition, require sufficient security to be given for those costs and costs of the provisional curator ad litem before a provisional order is made."

Under the section, if the court was satisfied that all the requirements under section 266(3)(a) and (b) were satisfied, then the court would appoint a provisional curator ad litem who had to report back to the court on the return day. ${ }^{92}$ On the return day, the court could do one of two things: (a) discharge the provisional order; or (b) confirm the appointment of the curator ad litem for the company and issue directions as to the institution of proceedings in the name of the company and the conduct of such proceedings on behalf of the company by the curator ad litem..$^{93}$

Only once the court had confirmed the appointment of the curator and issued directions as to the institution of proceedings in the name and on behalf of the company, could the action be referred to as a statutory derivative action. ${ }^{94} \mathrm{Up}$ to this point, the initiating shareholder would have been liable for the risk of costs, and the court in terms of section 268 could ensure that the initiating shareholder understands the consequences of instituting frivolous or vexatious claims. In doing so, the court was empowered to require the instituting shareholder to furnish security of costs if the court believed that the applicant would not be able to pay the costs of the respondent company. This amount could also include the costs associated with bringing the application (to appoint a provisional curator ad litem and the costs associated with the envisaged report to the court on the "return day") and the estimated costs of the provisional curator ad litem doing the initial investigation into the alleged wrongs of, or breaches by, the wrongdoers. Considering the above, it is not difficult to imagine the huge financial burden on an applicant shareholder who is required to provide security for costs, and why potential derivative claims might be abandoned

90 Du Plessis in Hugo and Kelly-Louw Essays on the Law of Banking, Companies and Suretyship 266.

91 Van Wyk de Vries Commission of Enquiry into the Companies Act par 42.16.

92 S 266(3) of the 1973 Act.

93 S 266(4) of the 1973 Act.

94 S 266(c) of the 1973 Act. 
on this basis.

It is clear from the above discussion, that the position regarding costs under the 2008 and 1973 Acts is inadequate and places too heavy a burden on applicants seeking to institute derivative proceedings, in effect amounting to a disincentive to institute proceedings. The position in the UK is somewhat unclear. The inconsistent approach by the courts regarding whether applicants would be indemnified for costs creates a very unstable environment and ultimately may result in extra costs and time being expended in trying to satisfy a court that the derivative proceedings are warranted.

It is submitted that to alleviate the burden on applicants and to provide for a shareholder-friendly approach that ensures equity between company and applicant, section 165(10) of the 2008 Act should be amended to provide an indemnity for a costs order that favours applicants who wish to institute derivative proceedings. This would ensure that applicants are incentivised to institute derivative proceedings and that wrongdoing would not go unpunished simply because of the hurdle of costs. The court should be allowed a discretion in deciding whether to grant the costs in full or in part.

The amended section 165(10) should read as follows:

"The court shall, on the application of the person to whom leave was granted under terms of subsection (2) to bring or intervene in the proceedings, order that the whole or part of the reasonable costs of bringing or intervening in the proceedings, including any costs relating to any settlement, compromise, or discontinuance approved in terms of subsection (15), must be met by the company. Such costs shall be paid by the company irrespective of the result of the application even if those costs are awarded against that applicant, unless the court considers that it would be unjust or inequitable for the company to bear those costs."

It is further recommended that section $165(11)$ be amended to read as follows:

"An order under this section (subsection (10)) must include security for costs."

Considering the proposed amendments above, it is submitted that section 165(9)(a) be amended to provide further clarity in respect of the identity of the "person appointed" under the section. It is submitted that the section be amended to indicate that the "person appointed" refers to the person appointed by the court under section $165(4)(a)$. If the person appointed refers to the person appointed by the court under section 165(4)(a), it would make sense for the company to be liable for the expenses in relation to that appointment. This is especially so when taking into account that the person appointed under section 165(4)(a) is appointed to investigate the merits of the demand, the facts that gave rise to the demand, the probable costs that would be incurred if the company pursued any such cause of action or continued any such proceedings, and whether it appears to be in the best interests of the company to pursue any such cause of action or continue any such proceedings. The scope of such an appointment only seeks to benefit the company. Therefore, it is submitted that the company should be liable for 
the expenses associated with that appointment. Furthermore, if the person under section 165(9)(a) were to refer to the applicant under subsection 2 this would only have the effect of potentially increasing the burden on an applicant and thereby discourage derivative claims.

It is therefore recommended that section 165(9)(a) be amended to read as follows:

“(9) If a court grants leave to a person under this section-

(a) the court must also make an order stating that the company is liable for the remuneration and expenses of the person appointed in terms of subsection (4)(a)."

Section 165(15) provides that derivative proceedings brought or intervened in with leave of the court "must not be discontinued, compromised or settled without leave of the court". ${ }^{95}$ The UK Rule $19.9 \mathrm{~F}$ of the Civil Procedure Rules provides that once a court has granted permission for the derivative proceedings to continue, then the claim constituted by that derivative action cannot be discontinued, settled or compromised without the court's permission. It is submitted that the position in South Africa is preferable as the power to grant permission for the derivative proceedings to be discontinued, settled or compromised is left within the sole discretion of the court. Furthermore, it is submitted that the South African approach is sounder because not only does section 165 give the court control over any settlements made in the derivative proceedings, but the section makes it compulsory for the court to grant permission for any discontinuance of the proceedings. In doing so, the court is obliged to weigh up the interests of the company and relevant persons, thereby ensuring fairness in the settlements or compromises reached.

95 See Cassim The New Derivative Action Under the Companies Act (2016) 21; see also Du Plessis in Hugo and Kelly-Louw Essays on the Law of Banking, Companies and Suretyship 274; Lewis Group Ltd $v$ Woollam supra. 